\title{
Sexual dimorphism in cranial dimensions among three ethnic groups of North-Eastern Nigeria
}

\author{
M. B. Maina, O. Mahdi and G.D. Kalayi \\ Department Of Human Anatomy, College of Medical Sciences, \\ Gombe State University, Tudun Wada Quarters, Gombe
}

\begin{abstract}
The study of sexual dimorphism is important clinically, in forensic anthropology and craniometry. Therefore this study was design to identify the sexual dimorphisms in cranial dimensions among three ethnic groups of North-Eastern Nigeria and to compare this study with other similar studies. Cranial length, width, height and circumference in Fulani, Tangale and Tera ethnic groups were linearly measured in a total of 300 (150 males and 150 females) 18-40 years old subjects. The result showed that all cranial dimensions among the three ethnic groups are higher in males than in females, except cranial width which is higher in Fulani $(138.7 \pm 10.4 \mathrm{~mm})$ than in their male counterparts $(136.8 \pm 10.6 \mathrm{~mm})$. The most prominent difference in cranial dimensions between the males and females among the three ethnic groups is in cranial length where males values are significantly higher than females values $(p<0.005)$. Interestingly, the values of cranial width were found to fluctuate between males and females. Therefore, the findings from this study revealed that sexual dimorphism exists between Fulanis, Tangales and Teras of Gombe and based on comparison with other studies we postulate that the effect of gender on cranial width is not consistent. Furthermore, the study confirms the effect of ethnic and geographic difference on cranial dimensions.
\end{abstract}

Keywords: North-Eastern Nigeria, Ethnicity, Sexual dimorphism, cranial dimensions.

\section{INTRODUCTION}

Sexual dimorphism is the difference best observed based on phenotype between males and females of the same species. Study of sexual dimorphism is important clinically, in forensic anthropology as well as in craniometry. Craniometry is a branch of anthropometry through which cranial dimensions can be estimated. The most important of craniometric dimension are height and width of head that they used in cephalic index determination (Vojdani et al. 2009). Cranial dimensions are not stable during earlier years of life due to further development such as the closure of anterior and posterior fontanel, but are stable over time (between 20-80 years) (Cotton et al., 2005). In early life there is little difference between male and female skulls, in adulthood male skulls tend to be larger and more robust than female skulls, which are lighter and smaller, with a cranial capacity about 10 percent less than that of the male (Gray's Anatomy 1935). A well-marked male or female skull can easily be recognized as such, but in some cases the respective characteristics are so indistinct that the determination of the sex may be difficult or impossible. Several studies have documented various sexual dimorphisms related to craniometry (Maina et al. 2011; Raji et al. 2010; Vojdani et al. 2010; Golalipour et al. 2005). Furthermore, ethnic, ecological, biological, geographical, racial, age and nutritional factors also affect cranial dimensions (Golalipour et al., 2003, Rajlakshmi et al., 2001, Radovic et al., 2000, Tuli et al. 1995 and Okupe et al., 1984) making it difficult to identify the sex of a skull without knowledge of the population from which it came.

Cranial dimensions of newborns are not stable because cranial length, height and width increase as growth progress (Trenouth, 1991), hence, this study was undertaken in adult males and females Fulani, Tangale and Tera to observe sexual dimorphism in their cranial dimensions and to compare this study with other similar studies.

\section{MATERIALS AND METHODS}

Subjects: This study was conducted on 18-40 years normal randomly selected Fulanis, Tangales and Teras of Gombe state region of North-Eastern Nigeria origin, from March to June 2011. Gombe State lies in the centre of the North-East geopolitical zone of Nigeria. It shares a common boundary with all the other states in the zone, namely, Adamawa, 
Bauchi, Borno, Taraba, and Yobe. A total of 300 subjects (150 males and 150 females) were used. Prior and informed consent was obtained from the subjects, and the study was carried out after obtaining clearance from the ethical committee of Federal Medical Centre Gombe, Nigeria.

\section{Craniometric measurements: cranial} measurements were taken after careful palpation with subjects in a relaxed condition with head in the anatomical position using standard anatomical landmarks (Lobo et al., 2005). Using a spreading calliper three head measurements (cranial length, width and height) were measured, while cranial circumference was taken using measuring tape as described below:

- Cranial length (linear length from Glabella to Inion).

- Cranial width (linear length between parietal eminences).

- Cranial height (Length from nasion to Gnation)

- Cranial circumference was taken as the length of the tape from a point slightly above the glabella, supercilliary arch and superior margin of the external acoustic meatus round via the inion and back to the point above the glabella.

Statistical Analysis: Data obtained from the subjects were recorded on a recording sheet, and then transferred into SPSS 11.0 for analysis. The means obtained from this study were subjected to analyses of variance (ANOVA) for assessment of statistical significance and linearity with a probability level of less than 0.05 considered significant.

\section{RESULTS}

The findings from this study showed that all cranial dimensions among the three ethnic groups are higher in males than in females, except cranial width which is higher in Fulani females who presented with $138.7 \pm 10.4 \mathrm{~mm}$ than in their male counterparts who presented with $136.8 \pm 10.6 \mathrm{~mm}$ (Table 1 \& 2). Inter ethnic comparison of cranial parameters in males and females showed various variations among the three tribes (Table 1\& 2).

Table 1: Means of cranial parameters among the three ethnic groups in males

\begin{tabular}{|l|l|l|l|l|}
\hline & $\begin{array}{l}\text { Cranial length } \\
(\mathbf{m m})\end{array}$ & Cranial Width $\mathbf{( m m})$ & Cranial Height $\mathbf{( m m})$ & $\begin{array}{l}\text { Cranial Circumference } \\
(\mathbf{m m})\end{array}$ \\
\hline Fulani & $191.7 \pm 7.1^{\star \star \star}$ & $136.8 \pm 10.6$ & $149.6 \pm 10.8^{\star \star \star}$ & $564.7 \pm 23.7^{\star \star \star}$ \\
\hline Tangale & $189.5 \pm 9.4^{\star \star \star}$ & $141.6 \pm 7.9$ & $146.3 \pm 8.2$ & $568.1 \pm 16.3$ \\
\hline Tera & $192.2 \pm 7.3^{\star \star \star}$ & $140.9 \pm 7.4^{\star}$ & $149.0 \pm 7.4^{\star \star \star}$ & $567.1 \pm 44.8$ \\
\hline Total & $191.1 \pm 8.1^{\star \star \star}$ & $139.8 \pm 8.9$ & $148.2 \pm 8.9^{\star \star \star}$ & $566.7 \pm 30.4$ \\
\hline
\end{tabular}

*signifies significance between head dimensions in males (Table 1) and females (Table 2)

Table 2: Means of cranial parameters among the three ethnic groups in females

\begin{tabular}{|l|l|l|l|l|}
\hline & Cranial length & Cranial Width & Cranial Height & Cranial Circumference \\
\hline Fulani & $181.2 \pm 10.2$ & $138.7 \pm 10.4$ & $144.1 \pm 8.9$ & $537.5 \pm 16.1$ \\
\hline Tangale & $181.2 \pm 10.2$ & $138.7 \pm 10.4$ & $144.1 \pm 8.9$ & $565.2 \pm 20.5$ \\
\hline Tera & $180.8 \pm 10.7$ & $136.9 \pm 9.5$ & $136.9 \pm 11.8$ & $558.8 \pm 45.2$ \\
\hline Total & $184.00 \pm 11.02$ & $140.1 \pm 10.9$ & $138.2 \pm 10.9$ & $561.5 \pm 29.7$ \\
\hline
\end{tabular}

\section{DISCUSSION}

The mean cranial length, width, height and circumference were higher in males among all the ethnic groups than in their female counterparts, except in Fulani females, where cranial width is higher than in their male counterparts. This agrees with the work Golalipour et al. (2005) that reported a mean cranial width of $150.4 \pm 7.2 \mathrm{~mm}$ in Fars females and $149.3 \pm 10.0$ in Fars males and Vojdani et al.
$18.76 \pm 0.61 \mathrm{~cm}$ in girls and $15.17 \pm 0.72 \mathrm{~cm}$ in boys. The most prominent difference in cranial dimensions between the males and females among the three ethnic groups is in cranial length, where the values in males are significantly higher than those in females $(p<0.005)$ (Table 1\& 2). These differences that exist between males and females have been reported to be likely due to differences in genetic make-up and inheritance which manifest as sexual dimorphism (Oladipo et al., 2006; Oladipo et al., 2007; Daniel, 
2002). The sexual dimorphisms observed can also arise due the difference in the levels of testosterone between males and females, because testosterone brings about a direct increase in the size and mass of muscles and bones, and thus changes in the shape of the face (Osunwoke et al. 2011).

On the basis of ethnicity, no significant inter ethnic difference in the cranial dimension exists between all the ethnic groups. This could be because the main factor that differentiate the three ethnic groups is ethnicity, but they dwell in the same habitat, and share similar nutritional condition, interestingly, they migrated from the same region.

The mean cranial length, width, height and circumference were higher than in our study on the assessment of cranial capacity on north-eastern Nigerian population (Maina et al. 2011), except in females where the mean cranial height and circumference from our previous study are higher than in this work (Table $3 \& 4$ ). The mean cranial length and height in both males and females are higher than in our previous report on morphological evaluation of head and face shapes in a northeastern Nigerian population (Raji et al. 2010), the mean cranial circumference however in this previous report is higher than in this study. The mean cranial length and height from this study are higher than those of Iranians reported in the work of Golalipour et al. 2005 in Turkman and Fars males and females; they are also higher than in Sri Lanka student's males and females (Ilayperuma 2010; Ilayperuma 2011), except in Sri Lanka student's females where cranial height is higher than in the females of this study (Ilayperuma 2011). The mean cranial length, width, height and circumference reported by Deshmukh and Devershi (2006) on Indian skulls were lower than those reported in this study. Cranial height from this study is also higher than those of Madhya Pradesh state of the India (Gohiya et al. 2010). However, variations exist in the values of cranial width from this study and other similar studies as depicted in Table $3 \& 4$ ). These difference observed among different studies with this study further confirms the effect of ethnic/racial and geographical factors on cranial dimensions as reported in some studies (Golalipour \& Heydari, 2004-5; Bayat \& Ghanbari, 2010; Garba et al., 2008, Okupe et al.
1984). It also confirms the influence of climatic or dietary affiliation on craniofacial dimensions as reported by Buretic et al. (2007) who observed that Mediterranean diet was associated with higher head length and head circumference measures in females while Mediterranean climate was associated with higher and narrower faces in females.

These findings also revealed that mean cranial length in males and females are higher than in Ibibios of Nigeria (Oladipo et al., 2010a) who had 19.06 \pm 0.77 $\mathrm{cm}$ and $18.80 \pm 0.77 \mathrm{~cm}$ in males and females respectively, but the mean cranial widths are lower than the Ibibio's, which were $15.20 \pm 0.71 \mathrm{~cm}$ and $14.70 \pm 0.67 \mathrm{~cm}$ in males and females respectively. The cranial lengths are also higher than those of Gurung community of Nepal (Lobo et al. 2005) who presented with $180 \pm 0.85 \mathrm{~cm}$ and $17.4 \pm 0.78 \mathrm{~cm}$ in males and females respectively, while the mean cranial width are lower than those of the Gurung community which were $14.9 \pm 0.83$ and $14.7 \pm 0.60$ in males and females respectively. The cranial circumferences from this study are also higher than in Omoku adult males and females who had $55.72 \pm 2.79$ $\mathrm{cm}$ and $54.89 \pm 2.82 \mathrm{~cm}$ respectively (Oladipo et al. 2010b).

Interestingly, dimensions like cranial length and height are usually higher in males than in females as demonstrated in many studies (Maina et al. 2011; Raji et al. 2010; Lobo et al., 2005, Ilayperuma 2010; Gohiya et al. 2010) but, cranial widths are sometimes higher in females than in males and sometimes slightly higher in males than in females and sometimes the values are equal. Parson and Keene (1918) reported that the female skull is shorter in proportion to its breadth than is the male by $2 \%$ and that this difference is not fully accounted for by the greater development of the frontal sinuses in the male. Vojdani et al. 2009 reported higher cranial width in girls than in boys; Golalipour et al. (2005) also reported a higher cranial width in Fars female than in their male. Cranial width was only slightly higher in males than in females in our previous studies (Raji et al. 2010 and Maina et al. 2011). While cranial width between males and females are almost equal in the work of Bayat and Ghanbari where females had 92.1 \pm 5.9 and males had 92.2 \pm 5.7 . In this study, the mean cranial width was also higher in females $(140.1 \pm 10.9 \mathrm{~mm})$ than in males $(139.8 \pm 8.9)$, 
thus this suggests that the effect of gender on cranial width is not consistent and confirms the findings that climatic features affect craniofacial traits in females, such as cranial breadth and head length in males (Buretic et al., 2007).

Table 3: Comparison of means of cranial dimensions in males with similar studies

\begin{tabular}{|l|l|l|l|l|l|}
\hline Location/Refefrence & $\mathbf{N}$ & Cranial length & Cranial Width & Cranial Height & $\begin{array}{l}\text { Cranial } \\
\text { Circumference }\end{array}$ \\
\hline $\begin{array}{l}\text { North-Eastern Nigeria/ } \\
\text { Maina et al. 2011 }\end{array}$ & 150 & $191.11 \pm 6.4 \mathrm{~mm}$ & $135.90 \pm 12.9 \mathrm{~mm}$ & $145.15 \pm 7.5 \mathrm{~mm}$ & $564.51 \pm 14.1 \mathrm{~mm}$ \\
\hline $\begin{array}{l}\text { Northeastern Nigeria/ Raji } \\
\text { et al. 2010 }\end{array}$ & 200 & $19.08 \pm 0.68 \mathrm{~cm}$ & $13.70 \pm 1.19 \mathrm{~cm}$ & $16.69 \pm 9.60 \mathrm{~cm}$ & $57.25 \pm 4.38 \mathrm{~cm}$ \\
\hline India/ Gohiya et al. 2010 & 200 & $191.270 \pm 6.903 \mathrm{~mm}$ & $145.615 \pm 5.908 \mathrm{~mm}$ & $130.025 \pm 7.206 \mathrm{~mm}$ & - \\
\hline $\begin{array}{l}\text { Indian/ Deshmukh \& } \\
\text { Devershi 2006 }\end{array}$ & 40 & $173 \pm 6.04 \mathrm{~mm}$ & $131 \pm 4.96$ & $132 \pm 5.59 \mathrm{~mm}$ & $496 \pm 13.32 \mathrm{~mm}$ \\
\hline Sri Lanka/ Ilayperuma 2010 & 200 & $180.00 \pm 11.12 \mathrm{~mm}$ & $140.15 \pm 10.66$ & $141.10 \pm 9$ & - \\
\hline Sri Lanka/ Ilayperuma 2011 & 220 & $180.5 \pm 13.22 \mathrm{~mm}$ & $147.80 \pm 5.53$ & $140.20 \pm 10.35$ & - \\
\hline Present study & 150 & $\begin{array}{l}191.14 \pm 8.1 \mathrm{~mm} \\
19.11 \pm 0.81 \mathrm{~cm}\end{array}$ & $\begin{array}{l}139.8 \pm 8.9 \mathrm{~mm} \\
13.98 \pm 0.89 \mathrm{~cm}\end{array}$ & $\begin{array}{l}148.2 \pm 8.9 \mathrm{~mm} \\
14.82 \pm 0.89 \mathrm{~cm}\end{array}$ & $\begin{array}{l}566.7 \pm 30.4 \mathrm{~mm} \\
56.67 \pm 3.04 \mathrm{~cm}\end{array}$ \\
\hline
\end{tabular}

Table 4: Comparison of means of cranial dimensions in females with similar studies

\begin{tabular}{|l|l|l|l|l|l|}
\hline Location/Refefrence & $\mathbf{N}$ & Cranial length & Cranial Width & Cranial Height & $\begin{array}{l}\text { Cranial } \\
\text { Circumference }\end{array}$ \\
\hline $\begin{array}{l}\text { North-Eastern Nigeria/ } \\
\text { Maina et al. 2011 }\end{array}$ & 150 & $183.53 \pm 9.9 \mathrm{~mm}$ & $135.47 \pm 14.9 \mathrm{~mm}$ & $141.29 \pm 7.6 \mathrm{~mm}$ & $570.03 \pm 26.7 \mathrm{~mm}$ \\
\hline $\begin{array}{l}\text { Northeastern Nigeria/ Raji } \\
\text { et al. 2010 }\end{array}$ & 143 & $18.39 \pm 0.80 \mathrm{~cm}$ & $13.57 \pm 1.29 \mathrm{~cm}$ & $14.10 \pm 0.87 \mathrm{~cm}$ & $57.22 \pm 2.61 \mathrm{~cm}$ \\
\hline $\begin{array}{l}\text { India/ Gohiya et al. 2010 } \\
\text { Indian/ Deshmukh \& }\end{array}$ & 200 & $178.720 \pm 5.577 \mathrm{~mm}$ & $\begin{array}{l}138.740 \pm 6.123 \\
\mathrm{~mm}\end{array}$ & $\begin{array}{l}125.475 \pm 6.023 \\
\mathrm{~mm}\end{array}$ & - \\
\hline $\begin{array}{l}\text { Severshi 2006 } \\
\text { Sri Lanka/ Ilayperuma 2010 }\end{array}$ & 180 & $171.92 \pm 10.11 \mathrm{~mm}$ & $\begin{array}{l}136.15 \pm \\
11.02 \mathrm{~mm}\end{array}$ & $\begin{array}{l}135.38 \pm \\
12.16 \mathrm{~mm}\end{array}$ & - \\
\hline Sri Lanka/ Ilayperuma 2011 & 180 & $175 \pm 6.61 \mathrm{~mm}$ & $\begin{array}{l}141.11 \pm 7.41 \\
\mathrm{~mm}\end{array}$ & $\begin{array}{l}138.89 \pm 12.94 \\
\mathrm{~mm}\end{array}$ & - \\
\hline Present study & 150 & $\begin{array}{l}184.00 \pm 11.02 \mathrm{~mm} \\
18.40 \pm 1.10 \mathrm{~cm}\end{array}$ & $\begin{array}{l}140.1 \pm 10.9 \mathrm{~mm} \\
14.01 \pm 1.09 \mathrm{~cm}\end{array}$ & $\begin{array}{l}138.2 \pm 10.9 \mathrm{~mm} \\
14.78 \pm 3.40 \mathrm{~cm}\end{array}$ & $\begin{array}{l}561.5 \pm 29.7 \mathrm{~mm} \\
56.15 \pm 2.97 \mathrm{~cm}\end{array}$ \\
\hline
\end{tabular}

\section{CONCLUSION}

The findings from this study revealed that sexual dimorphism exists between Fulanis, Tangales and Teras of North-Eastern Nigeria and based on comparison with other studies we postulate that the effect of gender on cranial width is not consistent. Furthermore, the study confirms the effect of ethnic and geographic difference on cranial dimensions.

\section{ACKNOWLEDGEMENT}

We wish to record our appreciation to Aisha Umar Yaro, Abdulkadir Halliru, Hajara Isah Jibrin, Maisamari Chailau Abare, Maryam, the staffs and students of Gombe State University for their support and assistance during this study. 


\section{REFERENCES}

Bayat. P. B. and Ghanbari. A., 2010. Comparison of the Cranial Capacity and Brain Weight of Arak (Central Iran) with other Subgroups of Iranian Population. Int. J. Morphol., 28(1):323-326. doi: 10.4067/S071795022010000100047.

http://www.scielo.cl/pdf/ijmorphol/v28n1/art47.pdf

Buretic-Tomljanovic A., Giacometti J., Ostojic S., Kapovic M., 2007. Sex-specific differences of craniofacial traits in Croatia: the impact of environment in a small geographic area. Ann Hum Biol. 34(3):296-314. http://www.ncbi.nlm.nih.gov/pubmed/17612861

Cotton F., Euvrard T., Durand-Dubief F., Pachai C., Cucherat M., Ramirez R. F., Bonmartin A., GuihardCosta A.M., Tran Minh V.A., Vallee B., Froment J.C., 2005. Correlation between cranial vault size and brain size over time: preliminary MRI evaluation. $J$. Neuroradiol. 32(2):131-7. PMID: 15984405 http://www.ncbi.nlm.nih.gov/pubmed/15984405

Daniel (Dan'El) A. C. Racial Anthropology and Genetics of the Lebanese. Phoenician International Research Centre (PIRC). Retrieved from: http://www.phoenicia.org/ychromodrafteng.html

Deshmukh A.G. and Devershi D.B., 2006. Comparison of Cranial Sex Determination by Univariate and Multivariat Analysis. J. Anat.Soc. India, 55 (2) 48-51. http://medind.nic.in/jae/t06/i2/jaet06i2p48.pdf

Garba, S.H., A.I. Numan and I.G. Mishara, 2008. Craniofacial classification of normal newborns in Maiduguri metropolis, Nigeria. Int. J. Morphol., 26: 407-410. doi: 10.4067/S0717-95022008000200026. http://www.scielo.cl/scielo.php?script=sci_arttext\&pid $=$ S071795022008000200026\&lng=en\&nrm=iso\&ignor $\mathrm{e}=. \mathrm{html}$

Gohiya V. K.; Sudha S. and Sarita G., 2010. Estimation of Cranial Capacity in 20-25 Year Old Population of Madhya Pradesh, a State of India. Int. J. Morphol., 28(4):1211-1214.

http://www.scielo.cl/pdf/ijmorphol/v28n4/art35.pdf

Golalipour M. J. and Heydari K., 2004-05. Effect of the Ethnic Factor on Cranial Capacity and Brain Weight of Male Newborns in Northern Iran. Neuroembryol Aging; 3:146-148. doi: 10.1159/000094603. http://content.karger.com/ProdukteDB/produkte.asp? Aktion=ShowAbstract\&ArtikelNr=94603\&Ausgabe $=23$ 2100\&ProduktNr=227097

Golalipour, M.J., Haidari, K., Jahanshahi, M., Farahani, R.M., 2003. The Shapes Of Head And Face In
Normal Male Newborns In South-East Of Caspian Sea (Iran-Gorgan). J. Anat. Soc. India, 52(1) 28-31. http://www.indmedica.com/journals.php?journalid=8\&i ssueid $=35 \&$ articleid $=450$ \&action $=$ article

Golalipour, M.J., M. Jahanshaei and K. Haidari, 2005. Estimation of cranial capacity in 17-20 years old in south east of Caspian Sea Border (North of Iran). Int. J. Morphol., 23: 301-304. doi: 10.4067/S071795022005000400003.

//www.scielo.cl/pdf/ijmorphol/v23n4/art03.pdf

Ilayperuma I. 2011. Evaluation of Cephalic Indices:A Clue for Racial and Sex Diversity. Int. J. Morphol., 29(1):112-117.

http://www.scielo.cl/pdf/ijmorphol/v29n1/art19.pdf

Ilayperuma I., 2010. On the Prediction of Personal Stature from Cranial Dimensions. Int. J. Morphol., 28(4):11351140. http://www.scielo.cl/pdf/ijmorphol/v28n4/art24.pdf

Lobo, S.W., T.S. Chandrashekhar and S. Kumar, 2005. Cephalic index of Garung Community of Nepal-An anthropometric study. KUMJ., 3(11): 263-265. http://imsear.hellis.org/bitstream/123456789/46152/2/ kumj2005v3n3p.263.pdf

M.B. Maina, Y.C. Shapu, S.H. Garba, M.A. Muhammad, A.M. Garba, A.U. Yaro and O.N. Omoniyi, 2011. Assessments of Cranial Capacities in a North-Eastern Adult Nigerian Population. Journal of Applied Sciences, 11: 2662-2665. doi: 10.3923/jas.2011.2662.2665. http://scialert.net/abstract/?doi=jas.2011.2662.2665

Grays Anatomy, 1935. Sex Differences in Skull \& Craniology. Adopted from Professional health systems. http://www.prohealthsys.com/anatomy/grays/osteolog y/skullcran.php. Retrieved on 10- July - 2011.

Okupe, R.F., O.O. Cooker and S.A. Gbajumo, 1984. Assessment of fetal biparietal diameter during normal pregnancy by ultrasound in Nigerian women. $\mathrm{Br}$. J. Obstet. Gynaecol., 99: 629-632. PMID: 6743603. http://www.ncbi.nlm.nih.gov/pubmed/6743603

Oladipo, G. S., Okoh, P.D., Akande, P.A.,Oyakhire, M.O., 2010. Anthropometric study of some craniofacial parameters: head circumference, nasal height, nasal width and nasal index of adult Omoku indigenes of Nigeria. Am. J. Sci. Ind. Res., 2(1): 54-57. http://www.scihub.org/AJSIR/PDF/2011/1/AJSIR-2-154-57.pdf

Oladipo, G.S., I.U. Gwunireama and O.O. Asawo, 2006. Anthropometric comparison of nasal indices between the Igbos and Yorubas in Nigeria. Global J. Med. Sci., 5(1): 37-40. 
Am. J. Sci. Ind. Res., 2011, 2(6): 871-876

Oladipo, G.S., J.E. Olotu and B.C. Didia, 2007. Anthropometric study of nasal parameters of the Ogonis in Nigeria. Sci. Afr., 6(10): 69-71.

Oladipo, G.S., P.D. Okoh and E.E. Isong, 2010. Anthropometric Studies of Cephalic Length, Cephalic Breadth and Cephalic Indices of the Ibibios of Nigeria. Asian Journal of Medical Sciences, 2(3): 104-106. http://maxwellsci.com/print/ajms/v2-104-106.pdf

Osunwoke E.A., Amah-Tariah F.S., Obia O., Ekere I.M. and Ede O., 2011. Sexual Dimorphism in Facial Dimensions of the Bini's of South-Southern Nigeria. Asian Journal of Medical Sciences, 3(2): 71-73. http://www.maxwellsci.com/print/ajms/v3-71-73.pdf

Parsons, F.G. and Keene, L., 1919. Sexual differences in the skull. J. Anat. (Lond.), 54: 58-65. http://www.ncbi.nlm.nih.gov/pmc/articles/PMC126291 1/pdf/janat00597-0063.pdf

Radovic Zdenka, Muretic Zelimir, Nemirovskij Vera and Gazi-Coklica Vesna, 2000. Craniofacial Variations in a South Dalmatian Population. Acta Stomatol Croat, 34(4): 399-403. http://hrcak.srce.hr/index.php?show=clanak\&id_clana $\mathrm{k}$ _jezik=17578\&lang=en

Raji, J.M., S.H. Garba, A.I. Numan, M.A. Waziri and M.B. Maina, 2010. Morphological evaluation of head and face shapes in a North-Eastern Nigerian population.
Aust. J. Basic Applied Sci., 4: 3338-3341. http://www.insipub.com/ajbas/2010/3338-3341.pdf

Rajlakshmi, Ch., S.M. Shyamo, T.H. Bidhumukhi and S.L. Chandramani, 2001. Cephalic index of foetuses of manipuri population: A baseline study. J. Anat. Soc. India, 50: 8-10. http://medind.nic.in/jae/t01/i1/jaet01i1p8.pdf

Trenouth M.J., 1991. Relative growth of the human fetal skull in width, length and height. Archives of Oral Biology, Volume 36, Issue 6, Pages 451-456. doi:10.1016/0003-9969(91)90136-I. http://www.sciencedirect.com/science/article/pii/00039 9699190136I

Tuli, A., R. Choudhry, S. Agarwal, C. Anand and H. Garg, 1995. Correlation between craniofacial dimensions and foetal age. J. Anat. Soc. India, 44: 1-12. http://medind.nic.in/imvw/imvw14523.html

Vojdani Z., Bahmanpour S., Momeni S., Vasaghi A., Yazdizadeh A., Karamifar A., Najafifar A., Setoodehmaram S. and Mokhtar A. 2009. Cephalometry in 14-18 years old girls and boys of Shiraz-Iran high school. Int. J. Morphol. 27(1):101104. http://www.scielo.cl/pdf/ijmorphol/v27n1/art18.pdf 